\title{
MATERNIDADE: NOVAS POSSIBILIDADES, ANTIGAS VISÕES
}

\author{
Patricia Zulato Barbosa* \\ Maria Lúcia Rocha-Coutinho**
}

\section{RESUMO}

Este artigo apresenta os resultados de um estudo exploratório inicial desenvolvido com o objetivo de melhor entender como as mulheres estão encarando a maternidade, bem como a opção de adiá-la e/ou não ter filhos. Para tanto, foram entrevistadas quatro mulheres de classe média na faixa de 37 a 50 anos com uma carreira profissional, duas que optaram por não ter filhos e duas que optaram pelo adiamento da maternidade para depois dos 35 anos. Nossos resultados apontam para o fato de que, apesar de novas possibilidades terem se aberto para as mulheres, antigas visões, como a de que a realização de uma mulher passa obrigatoriamente pela maternidade, ainda prevalecem no discurso social.

Palavras-chave: maternidade, visōes, possibilidades

\section{Abstract}

MOTHERHOOD: NEW POSSIBILITIES, OLD VISIONS

This article presents a pilot study developed so as to better understand how women perceive motherhood, as well as the option to postpone it andlor not to have children. We interviewed four middle class women, aged 37 to 50, engaged in a professional career. Two of them chose not to have children and the other two postponed it to the late thirties. Our results indicate that, despite the fact that new possibilities were opened to women nowadays, old visions, such as the one that considers motherhood essential for the fully accomplishment of a woman, still prevail in social discourse.

Keywords: motherhood, visions, possibilities

* Programa EICOS (Universidade Federal do Rio de Janeiro).

** Programa EICOS (Universidade Federal do Rio de Janeiro)/UNIVERSO. 


\section{INTRODUÇÃO: A MATERNIDADE COMO OPÇÃO}

As últimas décadas do século XX foram marcadas por alterações nos valores, práticas e papéis sociais desempenhados pelos indivíduos. Dentre as mudanças mais significativas e de particular interesse para nosso estudo estão as que ocorreram em relação à mulher nas últimas décadas e que transformaram o seu papel e sua posição na sociedade (Biasoli-Alves, 2000; Rocha-Coutinho, 1994). Hoje, as mulheres das camadas médias e altas vêm conseguindo uma inserção social cada vez maior e, aos poucos, vêm alcançando uma situação de relativa igualdade com os homens, pelo menos no espaço público.

Atualmente, o adiamento da maternidade tornou-se um fato comum entre aquelas com uma carreira profissional. Existe uma coincidência entre os melhores anos na vida da mulher para a construção e consolidação de uma carreira e os melhores anos para que ela tenha filhos. As mulheres engajadas em sua ascensão profissional muitas vezes não querem interrompê-la em prol da maternidade, pois a carreira - assim como os cuidados envolvidos na criação de um filho, especialmente em seus primeiros anos de vida - exige uma dedicação quase que integral. A maternidade, desta forma, acaba por ser postergada.

$\mathrm{O}$ adiamento da maternidade, esperando firmar-se profissionalmente e conseguir independência econômica, se estende, em alguns casos, por tanto tempo que as condiçôes apropriadas nunca chegam, ou somente advêm quando a gravidez passa a ser de risco, e, então, o projeto de ser mãe pode tornar-se praticamente inviável para elas.

A chance de uma mulher engravidar começa a diminuir quando ela tem apenas 27 anos e, a partir dos 30, o aparelho reprodutor feminino começa a entrar em um processo de envelhecimento que aumenta os riscos de má-formação, doenças congênitas e aborto. Portanto, prolongar muito a decisão de ter um filho pode significar um risco grande, segundo as descobertas científicas recentes sobre o tempo biológico da mulher. A tentativa de adiar a maternidade para primeiramente investir na carreira profissional pode, deste modo, gerar dificuldades para a mulher que deseja ser mãe.

Contudo, como aponta Badinter (1985), ainda temos, com excessiva freqüência, uma tendência a confundir determinismo social e imperativo biológico. O dado biológico sempre foi considerado um aspecto importante na diferenciação entre os sexos. Assim, apesar de muitos acreditarem hoje que os comportamentos são produçôes socioculturais - isto é, são as necessidades e valores dominantes em uma sociedade que determinam os diferentes papéis sociais -, na cultura ocidental, a mulher quase sempre foi e, em grande parte, continua a ser vista a 
partir de sua natureza biológica, mais especificamente por sua capacidade de gerar e parir filhos, sendo ainda correntes no discurso social, a despeito dos questionamentos que vêm sendo feitos por vários estudiosos desta questão, noções como a do instinto materno (Badinter, 1985).

Trindade e Enumo (2002), em seu estudo sobre a infertilidade, ressaltam que, diferentemente da maternidade, que continua a ser representada como meta natural da mulher, um caminho que começa a ser trilhado desde o nascimento, sem qualquer referência ao processo de desenvolvimento, a paternidade só é vista como natural na vida do homem a partir de um determinado momento. É como se a mulher já tivesse nascido preparada para a maternidade, enquanto que o homem precisaria passar por um processo de amadurecimento para tornar-se preparado para a paternidade. Segundo as autoras, este tipo de crença mostra a difusão de explicações biológicas indevidamente apropriadas pelo discurso social. Na verdade, apenas a gestação e o parto são biologicamente definidos, mas tanto o exercício da maternidade quanto o da paternidade são fruto de um aprendizado social.

Há algum tempo, os conceitos de instinto e de natureza humana vêm sendo questionados. No entanto, mesmo essas idéias tendo sido rejeitadas, elas ainda perduram, de alguma forma, na visão atual de maternidade. No momento, ainda que se esteja abrindo cada vez mais espaço para uma multiplicidade de experiências femininas, elas continuam a ser mais ou menos submetidas a esses antigos valores sociais, cuja força não pode deixar de ser levada em conta. Assim, ao mesmo tempo que há um incentivo à profissionalização da mulher e uma cobrança por parte dos pais e da sociedade para que as meninas estudem e invistam em uma carreira profissional, permanece a expectativa de que um dia elas venham a cumprir seu "principal" papel, o de mãe.

Como conciliar, então, essas duas atribuições? As mulheres atuais encontram-se sem um referencial, sem modelos a seguir e, assim, têm que buscar novas formas de lidar com os problemas que a elas se apresentam agora e que são distintos daqueles que eram comuns às mulheres das geraçóes anteriores. No nível social, ainda não surgiu uma solução satisfatória para a sobrecarga decorrente de ter que conciliar e dividir-se entre o trabalho fora de casa e a família. Tal fato leva um número cada vez maior de mulheres de classe média a buscar soluções individuais, como reduzir o número de filhos, adiar a maternidade, ou, até mesmo, fazer sua opção pela carreira profissional, desistindo de outros projetos como a maternidade.

Com o surgimento da pílula anticoncepcional e a maior eficácia dos métodos contraceptivos, pode-se dizer que as mulheres - pelo menos as dos segmentos 
sociais mais altos - se tornaram responsáveis por sua sexualidade, podendo optar por ter ou não filhos e por quando tê-los, ou seja, elas se perguntam o que efetivamente querem e não mais cumprem um destino que lhes cabe pelo simples fato de terem nascido mulher. Antes voltadas para os desejos dos outros - um dos pilares da subjetividade feminina -, para a satisfação daqueles à sua volta, elas se voltam agora para seu crescimento e desenvolvimento pessoais, começando a produzir sua própria palavra e a consolidar progressivamente práticas sociais transformadoras, ainda que, algumas vezes, a um elevado custo, tanto social quanto subjetivo.

Bonini-Vieira (1997), em seu estudo sobre mulheres sem filhos, aponta para o fato de que a maternidade pode não representar um projeto relevante para algumas mulheres atuais que, contrariamente à expectativa social, decidem não se tornar mães. Para ela, a ideologia que condiciona o papel da mulher como destinado aos cuidados do lar e dos filhos - já que se trata de uma construção social, baseada em discursos que atribuem prioridade máxima na vida da mulher ao papel de mãe - pode, certamente, ser questionada e alterada.

A despeito disso, o caráter de construção social de que se reveste a condição feminina não é facilmente identificado, porque vem sendo há longo tempo legitimado por discursos científicos, filosóficos, políticos e religiosos. A história mostra, contudo, que o lugar e a valorização da maternidade no âmbito sociocultural se modificaram e variaram ao longo de diferentes momentos históricos e contextos culturais, respondendo a interesses sociais mais amplos, como os de ordem econômica, demográfica, política, entre outros.

Apesar das intensas mudanças por que vem passando a sociedade nas últimas décadas, pesquisas como a de Trindade e Enumo (2002) apontam para o fato de que a mulher infértil continua a ser vista como triste e incompleta. Segundo os autores, isto se daria porque as pessoas acreditam que elas estão impedidas de vivenciar o que é apontado como a fonte máxima da realização feminina, a maternidade. Além disso, acredita-se que essas mulheres são solitárias, frustradas e inferiores, entre outras coisas.

O que se pode observar no estudo de Trindade e Enumo (2002) é a manutenção de uma representação social da infertilidade que implica depreciação e estigmatização da mulher e que está intrinsecamente associada às representaçôes tradicionais da maternidade, ora vista como destino biológico, ora como valor social inseparável da concretização da identidade feminina.

No caso das que optam por não ter filhos, Abranches (1990) observa que a decisão de ser ou não mãe não se estabelece sem conflito e está associada tanto à disponibilidade interna para a maternidade quanto ao grau de favorecimento proporcionado pelas condições externas. A autora levanta, no entanto, questôes im- 
portantes para as quais devemos estar atentos para não fazer afirmaçóes e generalizações simplistas e precipitadas: Será que a mulher agora realmente adquiriu o supremo direito de optar por ser ou não mãe? Será que esta decisão constitui o tão esperado gesto de libertação de sua condição aprisionadora de mantenedora da espécie, ou será que ela está sendo levada agora a tomar decisões que, na verdade, não resultam de um desejo pessoal, mas, antes, do fato de ter assumido novos papéis e funções? Neste último caso, não estaria a mulher passando por um outro tipo de imposição social?

O que se pode observar, especialmente no caso das mulheres das camadas médias e altas, é que, de geração para geração, vem diminuindo cada vez mais o número de filhos, o que pode apontar, em parte, como assinala Rocha-Coutinho (2005), para o fato de que um número crescente de mulheres está descobrindo que a vida pode proporcionar outras experiências emocionantes e gratificantes além da maternidade. Além disso, algumas mulheres hoje vêm questionando, inclusive, se, de fato, desejam ou não ter filhos. Uma vez que esse questionamento já se apresenta, podemos dizer que, ao menos, uma abertura se faz possível. O que se espera é que esta opção se faça presente e não que ganhe status de uma nova imposição social. O desejo de ter ou não filhos é, sem dúvida, complexo, inspira sentimentos contraditórios e é difícil de precisar e isolar de toda uma rede de fatores, tanto psicológicos quanto sociais.

Tendo essas questões em mente, desenvolvemos um estudo exploratório inicial com o objetivo de melhor entender como as mulheres estão encarando a maternidade, bem como a opção de adiá-la e/ou não ter filhos e qual o papel da carreira profissional em suas vidas. Os pontos por nós levantados aqui são, entre outros: por que as mulheres optam por não ter filhos ou por adiar a maternidade? $\mathrm{O}$ que as mulheres pensam sobre aquelas que optam por não ser mães? Será que ser mãe hoje em dia é fundamental para que a sociedade aceite a mulher como um ser completo? Será que a mulher que não quer filhos hoje ainda é encarada como uma mulher menor ou incompleta? As mulheres acreditam ser possível conciliar carreira profissional e maternidade? Será que o sucesso na carreira é sentido por elas como mais importante do que ser mãe?

\section{Nosso ESTUdo}

Foram entrevistadas quatro mulheres na faixa etária de 37 a 50 anos, duas que optaram por não ter filhos e duas que optaram pelo adiamento da maternidade para depois dos 35 anos. Todas as entrevistadas trabalham fora, exercem profissões de nível superior e são casadas: M tem trinta e sete anos, é médica e optou por 
não ter filhos; H tem quarenta e nove anos, é pedagoga e também optou por não ser mãe; $S$ tem quarenta e três anos, é fisioterapeuta e tem uma filha de um ano; e C tem trinta e oito anos, é advogada e também tem uma filha de um ano.

Foram escolhidas mulheres de classe média porque acreditamos que elas têm maior acesso à informação e à utilização de métodos contraceptivos e, assim, maior controle sobre as funções reprodutivas. Além disso, por sua situação social relativamente privilegiada, a entrada no mercado de trabalho, além de um retorno financeiro, envolve um sentimento de realização pessoal, o que possivelmente torna ainda mais conflituosa e difícil a opção de conciliar casa e carreira. Por fim, de acordo com os resultados da pesquisa de Trindade e Enumo (2002) sobre infertilidade acima mencionada, a mulher de classe média é a que mais sente a pressão social para ser mãe.

Fizemos uso de entrevistas semidirigidas que foram gravadas com o consentimento das entrevistadas e, posteriormente, transcritas. Os textos resultantes dessa transcrição foram submetidos a uma análise de discurso (Rocha-Coutinho, 1998) a partir das seguintes categorias: decisão de ter ou não filhos; visão de maternidade; pressão externa; e relação com o trabalho.

Neste artigo apresentaremos apenas os dados relativos às três primeiras categorias.

\section{DECISÃO DE TER OU NÃO FILHOS}

Muitos fatores estão envolvidos na decisão das mulheres entrevistadas de adiar a maternidade ou de não ter filhos, o que pode ser um indicativo da complexidade com que a maternidade se apresenta na atualidade. Antes vista como uma conseqüência inevitável do casamento, hoje parece que ela é encarada mais como uma opção de vida que envolve diferentes questóes, como encontrar o parceiro certo, investir em uma carreira profissional, conquistar estabilidade financeira e afetiva, manter a liberdade, entre outros:

O primeiro fator foi trabalho, a gente sempre assim, teve muito envolvido com muita coisa, eu e meu marido [...] eu pro meu lado também comecei a seguir muito a filosofia mestrado, fui pra São Paulo, aquela coisa, morei um tempo no exterior, a cabeça também ficou diferente, então o primeiro fator foi, é, não querer parar de fazer o que fazia pra cuidar de filho e o segundo fator financeiro [...] e um outro fator, que parece bobagem, mas pra gente tem uma estima, a gente não queria deixar nosso estilo de vida $(\mathrm{M})$. 
Ah, eu acho que a gente gostava muito de viajar, de andar e de..., a gente gostava de sair e outras coisas, a gente achou que não ia fazer falta e realmente eu não acho que faz falta (risos) $(\mathrm{H})$.

Casar, porque eu não sou a favor desse negócio de produção independente [...] eu acho que toda criança tem que ter uma estrutura de família, pai, mãe, irmão se possível [...] por isso eu não tive filho antes (S).

Bom, primeiro porque a gente trabalhava, tava construindo uma carreira, né [...] então tava investindo em mim, queria ter meu dinheiro, uma vida legal, mais estável [...] também como te falei, a gente queria curtir o casamento, né, início, né, a gente não tinha muito tempo, então quando tinha queria ficar junto, sair, viajar, a gente sempre gostou muito de cinema, filmes, conhecer lugares novos [...] então estávamos bem sem filho (C).

Em um dos casos relatados, a decisão de não ter filhos foi tomada em conjunto, ou seja, foi discutida pelo casal, chegando-se à conclusão de que seria a melhor opção para ambos. No outro, o assunto nunca foi discutido abertamente pelo casal, mas o tempo foi passando e a maternidade nunca teve espaço em suas vidas:

Do casal, não foi uma decisão minha, só minha ou só dele, foi uma decisão, é assim, nós tomamos a decisão juntos $(\mathrm{H})$.

É uma coisa que não se toca, a gente sempre tem uma coisinha "ah, esse ano não dá”, é o consultório, é uma viagem, é a casa, é isso, é aquilo, é trocar de carro, sempre (M).

O fato de o marido não pressionar para ter um filho e/ou de esta também ser uma opção dele parece facilitar a decisão das mulheres, como se pode observar nas falas abaixo:

Eu sei que nós tomamos a decisão e foi uma decisão assim mesmo, em dupla, entendeu, não foi uma decisão sozinha, de jeito nenhum, ele concordou e eu também concordei $(\mathrm{H})$.

Talvez pelo A, pelo meu marido, também não forçar muito essa situação [...] então nunca pensei e por ele não pensar a gente continuou não pensando (risos) (M).

Cabe observar aqui que $\mathrm{M}$ acrescentou que ser mãe nunca esteve em seus planos: "Foi sempre, eu nunca me imaginei, eu me imaginava tudo, sempre me imaginei casada, trabalhando, tudo, mas filho é uma coisa que, sempre foi um plano muito, assim, muito longe da minha vida" (M). 
Já $\mathrm{H}$ imaginava, quando mais jovem, que teria filhos, porém, após um aborto espontâneo de uma gravidez não planejada, ela e o marido perceberam que a melhor opção para eles seria não ter filhos:

Ah, achava que eu ia ser mãe, que ia ter uma família, blablablá, aquilo tudo que todo mundo pensa, entendeu, mas aí eu vi que não era bem isso e a gente acabou optando por não ter filhos. [...] Cinco anos depois que eu me casei, eu engravidei, fiquei grávida uns três meses, aí eu perdi o nenê e quando eu perdi eu e meu marido decidimos, a partir daquele momento, não ter filhos.

Tanto $\mathrm{M}$ quanto $\mathrm{H}$ deixaram claro que filhos não têm muito espaço em suas vidas, não apenas pelo trabalho que dão como também por uma questão de opção pessoal:

É por mim mesmo, é pela..., é meu jeito de ser, me dá uma preguiça, que eu acho sinceramente, só aquela criança chorando, eu não sei, é não querer se disponibilizar, não querer me disponibilizar, não ter essa pureza de espírito, (essa doação toda), eu acho, mas assim, a profissão claro que pesa, ter que deixar de fazer muita coisa que eu faço, mas não é só ela não, nem é um fator determinante para eu não ter filho, não $(\mathrm{M})$.

A gente achou que não ia fazer falta e realmente eu não acho que faz falta, tanto que os meus sobrinhos, eles vêm aqui, eles passeiam por aqui, ficam, às vezes, assim, é quinze dias, um mês, eu gosto, tudo, mas eu dou graças a Deus por não ter, entendeu (risos) $(\mathrm{H})$.

É interessante notar que $\mathrm{H}$, logo a seguir, diz ser egoísta, concepção muito pautada na idéia da maternidade como "ideal maior da mulher, único caminho para alcançar a plenitude, a cabal realização da feminilidade, em sincronia com a necessidade da anulação pessoal, da abnegação e do sacrifício prazeroso", como afirmam Trindade e Enumo (2002: 152). Assim, as mulheres que não querem filhos seriam egoístas, pois não saberiam fazer concessões em nome do filho:

Eu sou (um pouco egoísta sabe), eu gosto assim de na hora que eu quero deitar, eu boto as pernas pra cima, fico tranqüila, enquanto as minhas amigas estão (lá, literalmente ralando, sabe) e eu não, acho que eu não, não gostaria disso, eu não gostaria mesmo. [...] O ruim de ser mãe é que você [...] você perde totalmente a privacidade, você não tem mais, ah, eu quero sair agora, você tem que ver, porque você tem outras pessoas que dependem de você, você tem outras pessoas que moram com você, tem esse lado, então é o meu lado egoísta que tá 
falando agora [...] e o lado, ahn, bom de não ser mãe é o meu lado egoísta também [...] então esse é meu lado egoísta, é que você não tem muitas preocupações.

Quando questionadas sobre os riscos de uma gestação tardia, ambas as entrevistadas com filhos afirmaram estar cientes deles, mas acrescentaram que, com o avanço da medicina, hoje em dia há menos problemas, e que toda gestação, tardia ou não, envolve riscos:

Eu sempre quis ter, mesmo com os riscos, se bem que isso aí, hoje em dia é tudo tão assim relativo, porque você vai conversar com o ginecologista, o que que eles falam pra você, qualquer mulher pode gerar um filho doente, tanto as novas, tanto as velhas (S).

Sabia, mas hoje as coisas estão um pouco mais fáceis, né, e também quem ia garantir que se eu tivesse um filho mais cedo também não seria uma gravidez de risco, sabe, é claro que tem mais chances de ter algum problema quando a mulher é mais velha $(\mathrm{C})$.

Ainda em relação às mulheres que adiaram a gestação, $S$ diz não ter adiado por vontade própria, enquanto que $\mathrm{C}$ afirma que sim. Para $\mathrm{C}$ este foi o melhor momento para que a gravidez acontecesse:

No meu caso eu não sei te dizer se foi o melhor momento, se não foi o melhor momento, questão de preparação, eu nunca, nunca me senti despreparada, mesmo que eu fosse mais nova eu não me sentia despreparada pra ter filho, eu acho que foi a questão de como é que é, do destino, vamos dizer assim, eu não casei cedo, não encontrei, se [...] tivesse casado mais cedo, teria tido filho talvez mais cedo, mas não ocorreu $(S)$.

Acho, acho, foi, porque, bom, eu tinha uma estabilidade financeira, meu trabalho, né, uma estabilidade emocional, né, por estar com uma pessoa especial [...] eu me sentir mesmo, assim, preparada pra ser mãe [...] tava mais consciente das coisas, do que ia ter pela frente, já podia optar, seria mais fácil conciliar o trabalho [...] já tinha aproveitado bastante [...] não mudaria as coisas não, acho que foi uma decisão bem tomada, assim, pra mim, pro meu marido (C).

\section{VISÃO DA MATERNIDADE}

A maternidade, no discurso de todas as entrevistadas, foi vista como algo único, especial na vida da mulher: 
Ah, ser mãe é muito bom, na minha opinião assim, acho que é muito bom [...] é uma coisa, um sentimento muito forte, grandioso, acho que é isso, vamos dizer assim, é tudo grande, entendeu, o sentimento, o amor que você sente, a responsabilidade também (C).

Deve ser um amor acima de qualquer coisa [...] mas é uma coisa que você não pode enjoar, que não pode mudar, uma coisa decisiva na sua vida, muito decisiva $[\ldots]$ que você dá a vida, [...] deve ser um sentimento muito nobre que te muda muito (M).

Além de afirmar que a maternidade é uma coisa "muito decisiva”, que não pode ser mudada, quando perguntada sobre o que era ser mãe, $\mathrm{M}$ usou o ditado "ser mãe é padecer no paraíso", o que implica a conjugação de aspectos positivos e negativos, de recompensas e sacrifícios:

É quase 99\% das pessoas, eu escuto "é muito bom, é muito bom, mas aproveita que tua vida muda pra sempre”, ué, eu acho, na minha maneira, é contraditório, "aproveita sua vida com o A pra viajar, pra fazer as coisas que vocês gostam, pra trabalhar, porque depois muda tudo", então esse ser mãe eu acho que a frase mais normal, a frase comum, de lugar comum, é a mais verdadeira, padecer no paraíso, é aquele amor louco, mas você deve padecer, porque senão ninguém falaria isso.

$S$ também citou este ditado quando falou sobre os sacrifícios da maternidade:

O lado ruim, vamos dizer assim, que não é tão ruim [...] é uma coisa que você faz de coração, você não faz obrigada, você não fica sem dormir obrigada, você não levanta de madrugada obrigada, entendeu, você levanta com sono? Levanta. Cansada, com dor nas costas? Levanta [...] você fica estourada, mas você não acha que aquilo é a pior coisa do mundo, são sacrifícios que você tem que fazer, porque, pôxa, a criança depende de você [...] então são sacrifícios que você tem que fazer [...] é a cota de sacrifício que a gente tem que dar, né, como diz o ditado "ser mãe é padecer no paraíso", o ditado até que é bem feito (S).

Como se pode ver acima, as falas de $\mathrm{M}$ e $\mathrm{S}$ trazem o ideário do devotamento e do sacrifício, a visão da maternidade como um sofrimento voluntário e indispensável para a mulher normal, o que ainda hoje parece estar fortemente presente no pensamento social.

Para as duas entrevistadas que não têm filhos, o lado bom de ser mãe é diminuir o risco da solidão. Mesmo não sendo garantia de companhia no futuro, os filhos aplacariam um pouco esse medo: 
O bom de ser mãe é que você, ahn, ... tem menos medo de ficar sozinho, entendeu [...] que o lado bom seria esse, que você teria uma casa com filhos, você constituiria uma família, você sempre teria um renovar das coisas [...] então você pode até perder o medo um pouco de ficar sozinha, mas como eu já disse, isso não indica que você não vá acabar num asilo só porque tem [...] e por outro lado, o lado ruim de não ser mãe é você ficar com esse medo da solidão $(\mathrm{H})$. Num momento ou outro você vê assim, "nossa, já pensou se acontece de eu ficar sozinha"? (M).

Para as duas, o lado ruim de ser mãe é a perda da liberdade que se tem quando não há outra pessoa com quem se preocupar, que dependa de você:

O ruim de ser mãe é que você [...] perde totalmente a privacidade, você não tem mais, ah, eu quero sair agora, você tem que ver, porque você tem outras pessoas que dependem de você, você tem outras pessoas que moram com você, né, tem esse lado, [...] então esse pra mim é o lado ruim, sabe, de você sempre estar na dependência do bem-estar de alguém $(\mathrm{H})$.

O lado bom de não ter filho é aquela coisa a gente pra gente mesmo, é mais fácil levar quando você não tem ninguém dependendo de você, porque [...] uma criança depende pra tudo de mim, entendeu, dependeria pra tudo da gente, então é aquela coisa assim, eu acho muito pesado, uma responsabilidade muito séria $(\mathrm{M})$.

Não só as entrevistadas que não têm filhos falaram sobre esses dois lados da maternidade. Também $\mathrm{C}$ afirma:

Uma coisa que eu pensava, que acho que as pessoas pensam mesmo, é de ficar um pouco sozinho, né, não ter filhos, não ter netos, ficar só você e o seu marido, e depois que um morrer, imagina, você vai ficar ainda mais sozinho, então, não era uma coisa que eu queria pra mim [...] não sei como vai ser, né, pode ser que seja assim do mesmo jeito, mesmo tendo filho, porque ela vai ter a vida dela e tudo, mas acho que não, vai ser mais vivo, vamos dizer assim. [...] O bom de não ser mãe é que você tem mais tempo pra você, tem mais dinheiro pra você, você tem menos preocupaçôes, menos responsabilidade, você pode fazer as coisas do seu jeito, na hora que quiser sair, você sai, quer viajar, viaja, quer gastar dinheiro, gasta, é mais tranqüilo, entendeu.

O que mais diferencia a maternidade atual da de gerações anteriores, segundo as entrevistadas, é que a maioria das mulheres agora trabalha fora. Também 
foram citadas as condiçôes econômicas e sociais, que, para elas, hoje são bem mais difíceis do que outrora:

A vida é que tá diferente, que a minha mãe não trabalhava fora, né, como a maioria das mães da época dela, a maioria, era uma ou outra que trabalhava fora, a maioria era dona-de-casa, né, então, as coisas eram mais fáceis, você não precisava botar filho na creche, você não precisava botar o filho na escola cedo, você podia cuidar do seu filho em casa, hoje que a vida mudou, então a gente tem que girar conforme as mudanças $(\mathrm{S})$.

Era tudo mais fácil, tinha mais dinheiro, normalmente a mulher não trabalhava, se trabalhava dava pra conciliar, tinha empregadas, tinha babá, era diferente (M). Acho que criar um filho era mais fácil, financeiramente, socialmente [...] outra coisa, educar eu acho que tá dificílimo (M).

Para $\mathrm{H}$, a conseqüência maior do fato de a mulher trabalhar fora de casa é a culpa e a necessidade de ter que compensar a falta de tempo que passa com os filhos: "Acho, acho muito diferente, porque a maioria das mães trabalha fora, então é exatamente isso, eu acho que elas se culpam por não estar com os meninos, com as crianças [...] elas querem ahn, cobrir essa falta com coisas materiais, com um certo exagero de alguma..., de permissões".

M também se referiu a esse comportamento compensatório das mulheres que trabalham fora, o que levaria as crianças de hoje, segundo ela, a serem muito mal-educadas: "Que as mães por trabalharem tanto fora, as crianças são muito mal-educadas e quando chegam em casa têm aquela síndrome da mãe ausente, faz tudo o que a criança quer".

Para C, o fato de as mães antigamente terem mais tempo para os filhos não significa que elas tinham uma relação melhor com eles; apenas, as mulheres hoje têm que se dividir mais: "Elas tinham mais tempo, mas também, o que não significa que isso era melhor, entendeu?, não é isso que eu quero dizer, só que era diferente, hoje a mulher tem que se dividir mais".

Por fim, C lembrou também que hoje o número de filhos é menor:

Outra coisa também, acho, eu acho que elas tinham mais filhos, hoje não, hoje é um ou dois, né, não tem muito aquelas famílias de seis, sete irmãos, assim, que eu digo, na nossa classe, né, tô falando das pessoas que têm mais instrução, que têm condições de se prevenir, e tudo, então, essas famílias são raras, estão menores, entendeu, eu vejo essas diferenças. 
M comentou que a cobrança sobre as mulheres para ter filhos na época de sua mãe era também maior: "É, protocolo social, né, você tinha que casar e depois tinha que ter filho, que ainda é hoje, imagina naquela época".

Muitas características foram citadas ao tentar descrever uma mãe "ideal", como observar o filho, estar presente, dar apoio, impor limites. Contudo, para as entrevistadas não existiria na verdade uma mãe ideal:

Sei lá, eu acho que não existe modelo de mãe ideal, acho que não existe, acho que mãe é mãe, com defeitos, com qualidades, como todo ser humano, [...] acho que você tem que ter muita intuição, observar muito a criança, o seu filho, mas acho que não existe modelo de mãe ideal (S).

Mãe ideal, sinceramente, não sei te responder essa pergunta [...] eu não sei o que que é mãe ideal, acho que nem tem, acho que elas fazem o melhor, gente, porque [...] nas mães que eu conheço tem um instinto maternal super apurado, são boas pessoas, pessoas de boa índole, bom coração e erraram tanto, então eu acho que não tem um ideal aí, elas fazem, tenho certeza, que o melhor (M). Essa mãe que procura o melhor pro filho, né?, ideal acho que nunca vai ser, mas procurar ser, já é o suficiente, né?, não é ficar paranóica querendo fazer o melhor, é seguir o coração, deixar as coisas acontecerem, né?, observar bem, procurar estar informada [...] saber sobre o que o filho faz, o que ele quer, conversar sempre, participar da vida da criança, entendeu, não é querer controlar tudo, mas estar presente quando a criança precisar, deixar claro pra criança que você tá por perto, que ela tem alguém em quem se apoiar [...] uma coisa importante é dar limites (C).

$\mathrm{O}$ instinto materno foi percebido por elas de forma distinta. $\mathrm{M}$ e $\mathrm{H}$ fizeram uma associação da mulher com a fêmea do reino animal. Contudo, enquanto para $\mathrm{M}$ esse instinto surgiria com a gravidez, para $\mathrm{H}$ a mulher já nasceria com ele:

O instinto maternal eu acho que ele brota mesmo com, eu acho que isso existe em toda mulher, de, entendeu, existe em toda fêmea [...] todo mundo tem essa, essa tendência a proteger o filhote, né, então, mas, instinto é proteção do filho [...] na sua barriga, mas eu acredito que antes desse ponto, antes da nidação, antes do feto estar formado ali, existia, ninguém sabe bem, como eu, por exemplo, não sei onde tá, tá tão escondido (que eu não sei onde tá), ou existem outras pessoas que esse sentimento é mais aflorado, mas acho que esse instinto mesmo aparece e ele é determinado cientificamente no momento que já começa uma gestação aí (M). 
É um instinto, entendeu, eu acho que a gente já nasce assim, eu não [...] sou uma expert no assunto, mas eu imagino que esse instinto materno já nasce com a mulher, com a fêmea, né, os animais, elas já nascem assim, elas já são assim $(\mathrm{H})$.

Mesmo não fazendo uma associação da mulher com a fêmea, $\mathrm{C}$, como $\mathrm{M}$, acima, também mencionou a idéia de proteção ao filho como algo instintivo na mulher:

Sabe, eu acho que a mulher é diferente, porque a gente tem, talvez, assim, um instinto de proteção, de querer cuidar, de se preocupar, que é comum às mulheres, assim, a gente gera, né, leva na barriga, acontece tanta coisa no nosso corpo, na cabeça da gente também, né, depois é a gente que amamenta, então, não sei, parece que é algo instintivo, que vem com a gente (C).

É interessante que, mesmo defendendo a existência de um instinto materno, para as entrevistadas as mulheres teriam certo controle sobre ele, podendo optar por segui-lo ou não:

É, todo mundo tem o instinto materno, eu acho que todas as mulheres têm, entendeu, só que a vida leva você a fazer alguma coisa, depois, assim, você fazer a sua opção de ter filhos ou não ter filhos, o que não acontece com os animais $(\mathrm{H})$. Acho que é instintivo, mas em algumas esse instinto fala mais alto [...], talvez assim, tivesse uma gradação, sei lá, porque hoje a mulher tem tantas opções, ela pode optar pelo que quiser, então a vida vai fazendo com que o instinto fique lá no fundo, entendeu, é isso que faria a diferença, assim, a gente poder dizer o que quer, não precisar seguir o instinto, vamos dizer assim, a gente pode controlar, mais ou menos, esse instinto $(\mathrm{C})$.

$S$ foi a única a afirmar que o instinto materno não está presente em todas as mulheres:

Não, eu acho que não, acho que tem mulheres que talvez até não nasceram pra ter filhos e tem outras que já nasceram pra ter, pra ser mãe, pra cuidar, agora tem umas que eu noto, que eu observo que às vezes têm filhos, mas que não dão praquilo, talvez façam mais por obrigação, mas que não é uma coisa assim que venha de dentro, já vi algumas pessoas assim, não são, não é a maioria, mas tem.

Todas as entrevistadas disseram que a maternidade traz mudanças na vida da mulher. As que têm filhos especificaram o que mudou em suas vidas, seja no 
cotidiano, nos relacionamentos, no trabalho, e até mesmo em termos de algumas características pessoais:

Ah, mudou, minha vida toda, né, como eu falei pra você, minha vida não gira mais em torno de mim, minha vida gira em torno da minha filha, né, eu acordo de manhã já pensando em tudo, pensando como eu vou preparar a bolsa dela, qual roupa que eu vou botar, quantas fraldas, que que falta, então gira tudo em torno dela, fora que o dinheiro não sobra mais, o dinheiro vai todo (S).

Ah, mudou, eu trabalho agora só na parte da tarde, sabe, de manhã fico com ela [...] mas mudou, né, antes não tinha hora pra entrar, pra sair, levava trabalho pra casa, fim de semana se precisasse, trabalhava, agora tô me segurando, sabe, dá uma certa hora, saio, vô pra casa ficar com ela [...] a gente tem ido pouco ao cinema [...], quanto a mim, né, que você perguntou também [...] a preocupação é que mudou, entendeu, porque antes, antes era comigo, com meu marido, com o trabalho, agora é ela, sempre ela em primeiro plano, ela tá na frente de tudo (C).

Aquelas que não têm filhos apontaram a falta de disponibilidade como uma das principais mudanças acarretadas pela maternidade na vida das mulheres:

Acho que em tudo, disponibilidade, tempo, eu gosto de ser uma pessoa disponível, assim, a minha característica [...] se eu preciso cobrir um plantão, se preciso cobrir uma emergência, se precisa operar de madrugada, eu que vou, eu que sempre tenho tempo e eu não acho isso ruim não $(\mathrm{M})$.

Eu ia perder a minha tranqüilidade de fazer tudo o que quero na hora que eu quero, entendeu? (H).

As duas entrevistadas sem filhos disseram que talvez fossem boas mães. $\mathrm{M}$, no entanto, ressaltou que algumas mudanças teriam que ocorrer no seu modo de ser atual. H valorizou sua experiência de vida, lembrando, contudo, que é mais fácil falar do que fazer:

Acho que eu seria uma mãe que um filho gostaria de ter. Eu gosto de esporte, eu gosto de música [...] que o filho se orgulharia de ter uma mãe assim, entendeu, agora, como eu seria como mãe? Por exemplo, todo dia eu acordo atrasada, todos os dias [...] eu sou extremamente sistemática, extremamente metódica [...] então eu acho que eu já tô num esquema sistemático tão grande que eu acho que isso filho incomoda, [...] se um dia eu fosse mãe isso ia ter que mudar 
muito em mim, porque eu acho que é uma coisa que incomoda e cê vai ficando cada vez mais assim, tudo no lugar, não pode, não isso, não aquilo, é uma loucura (M).

Eu imagino que eu me sairia..., que eu talvez..., eu me saísse bem [...] hoje, por exemplo, eu me sairia muito bem, porque eu, depois de tantas experiências com os amigos, as amigas todas, [...] mas é, vê bem, é muito difícil porque quando você..., é aquela história, quando você não tem telhado de vidro é fácil você jogar pedra [...] não sei se um filho na minha frente, aqui no meu dia a dia, eu fizesse as coisas que eu estou pensando hoje, coisas até que eu não pensava muitos anos atrás, entendeu? $(\mathrm{H})$.

\section{PRESSÃO EXTERNA}

A mulher que não tem filhos parece ainda ser vista pela sociedade como uma coitada, como aponta $\mathrm{M}$ em sua fala: "É a coitada, é muito a coitada, ninguém vê que eu tô bem, feliz da vida, que filho, que não é uma coisa que é pra ser protocolada" (M).

Trindade e Enumo (2002), em seu estudo, apontam metáforas depreciativas utilizadas para se referir a mulheres que não têm filhos, sempre ancoradas na associação simbólica mulher-natureza ("tronco oco", "árvore sem frutos”, "árvore seca", "terra árida", entre outras). Em conjunto com termos e expressóes como "incompleta" e "pessoa inferior", elas sinalizariam a permanência do estigma da infertilidade feminina no pensamento social. Tal uso foi mencionado por uma das entrevistadas ao falar da cobrança de seu avô paterno porque sua mãe e sua tia estavam demorando a ter filhos: "Aí meu avô quando elas chegavam [...] quando minha mãe chegava e a minha outra tia chegava, aí, ele falava assim 'ih, chegaram as figueirinhas do inferno', porque figueira do inferno não dá fruto” (S).

Trindade e Enumo (2002) assinalam, ainda, que os estudos históricos e antropológicos raramente fazem referência à infertilidade masculina, o que sugere que os problemas reprodutivos do casal têm sido atribuídos às mulheres, engendrando metáforas e simbologias pejorativas e humilhantes nas representaçôes sociais. $S$ também se referiu a essa questão:

Ih, "fulana tem algum problema”, às vezes o problema nem era da fulana, era do fulano, né, mas aí as pessoas rotulavam, que o homem nunca tinha problema nenhum, sempre quem tinha problema era a mulher [...] porque antigamente não tinha espermograma, não tinha nada disso, então quem não tinha filho a culpa era da mulher que era má, enfim, não procriava e no final das 
contas, no caso da minha mãe não, mas no caso dessa minha outra tia, quem não fazia filho era meu tio, meu tio é que não fazia filho.

As que se sentiram mais cobradas pelas pessoas por suas opções relativas à maternidade foram $\mathrm{M}$ e $\mathrm{C}$. $\mathrm{H}$ afirmou que a cobrança só aconteceu no início de seu casamento e $S$ disse que nunca foi cobrada:

Ah, todo mundo fica perguntando, [...] ainda mais porque a gente já tinha um tempo de casados, [...] começam a cobrar mesmo (C).

A cobrança foi só no começo como eu te disse, depois que essa era de não ter filhos apareceu por aí, entendeu, aí eles pararam de cobrar [...] então, aí, nunca mais ninguém cobrou nada, porque eles viram que a gente não queria mesmo, entendeu $(\mathrm{H})$.

Não, não, nunca, eu não fui cobrada, porque eu não fiquei durante muito tempo casada assim, entendeu, talvez se ficasse mais e talvez até se eu fosse nova e ficasse esperando cinco, seis, dez anos, aí talvez houvesse cobrança por parte dos meus pais ou por parte da minha sogra $(S)$.

As mulheres afirmaram, ainda, que, apesar de desagradável, elas aprenderam a lidar, cada uma a seu modo, com essa insistência e intromissão alheia:

Então, às vezes é uma fuga, não me incomoda também que perguntem não, mas às vezes o ser incisivo enche a paciência, você ter que ficar justificando sempre com coisas que as pessoas não concordam, então, "ah, não sei, tô dando um tempinho, já parei de tomar o remédio, ainda não engravidei”, aí a pessoa, às vezes, pára de te perturbar um pouco, mas assim, é muito difícil, porque a cobrança social é muito grande e de pessoas da minha idade também (M).

Ah, é um pouco chato, né, porque você tem que dar satisfação da sua vida, mas como falei, você acaba se acostumando, vê que não é por mal, e depois você responde qualquer coisa, que eles se sentem satisfeitos com a resposta, eles querem saber de alguma coisa, depois pronto, passa, e também sei que não era só comigo, acontece com todo mundo, né, mas [...] tá todo mundo feliz, tô casada, tenho minha filha, meu trabalho, cumpri com minha obrigação (risos) (C).

$\mathrm{C}$, na fala acima, demonstrou alívio por não precisar mais responder a esta pergunta, uma vez que agora está atendendo às expectativas sociais. Já $\mathrm{H}$ diz nunca ter se importado em falar sobre o assunto: "Não, nunca me importei, do jeito que eu não me importo hoje, eu não me importava há dez anos atrás, há quinze anos atrás, entendeu, eu nunca me importei” $(\mathrm{H})$. 
$M$ foi quem mais enfatizou a existência de uma cobrança nesse sentido e também quem mais falou sobre a sua dificuldade em lidar com isso:

$\mathrm{Na}$ verdade a gente acovarda muito atrás dos nossos conceitos, eu não tenho coragem de falar assim "não quero filhos", eu sempre "não posso", "não dá", "não sei”, "será que eu posso? Nunca parei de tomar pílula". [...] Também acho que ninguém tem "não quero filhos", que é uma coisa assim que nem sempre soa bem, nem sempre é bom de ouvir, primeiro que a maioria das pessoas tem filho, então você tá primeiro depondo contra uma situação social, né, e segundo, é no foro íntimo mesmo, como mulher, eu não tenho muita coragem de dizer [...], a gente é sozinho nessa decisão, primeiro, os pais, principalmente os meus que são mais velhos, cobram demais filho, a sociedade nunca tá satisfeita e não adianta cê dizer que não fica influenciado pela cobrança, porque fica [...], todo mundo se influencia por isso.

A mentira muitas vezes faz parte das estratégias de $\mathrm{M}$ para lidar com a cobrança: "Começa 'não, tô planejando pro ano que vem', 'não, tô planejando', às vezes você até mente pra ficar livre do comentário, 'é, não sei, já parei de tomar, não sei porque não tô engravidando', aí a pessoa fica morrendo de pena de mim, de ter algum problema, aí já não pergunta mais”.

$\mathrm{H}$ tem uma opinião diferente. Ela acha que os casais que optaram por não ter filhos falam hoje abertamente sobre o assunto: "Começaram a aparecer os casais que por opção não queriam ter filhos, quer dizer, deveriam existir muitos, né, mas eles não estavam tão presentes assim, dizendo a toda hora que não queriam, hoje em dia quem não quer assume literalmente, eu conheço outros casais que não quiseram, que não querem".

Quanto ao fato de a mulher ter que ser mãe para ser completa, todas elas afirmaram que não e que percebem uma mudança na forma da sociedade encarar a opção de não ter filhos:

Não, acho que não, eu acho que a maternidade tem que ser um desejo seu, não por uma cobrança de sociedade, eu acho que hoje em dia não, no tempo da minha mãe, aí isso ocorria realmente, a mulher casava pra procriar, né, e no tempo da minha avó era pior ainda $(S)$.

Não necessariamente, eu acho que não, e como eu te disse, as pessoas estão tomando consciência disso, porque hoje eu vejo que aquelas que optam por não ser mãe, eu acho que elas são menos cobradas do que na minha época $(\mathrm{H})$. 
Para as entrevistadas sem filhos estão ocorrendo mudanças atualmente na forma como as pessoas e a sociedade encaram os papéis femininos:

Não, hoje com certeza a gente tem várias aberturas, mas eu acho que a minha geração tá sendo pioneira, entendeu, a gente é que tá mudando, minha geração que tá mudando [...] mas tá mudando, acho que justamente agora, nesse momento (M).

Atual, eu acho bem atual, dos anos noventa pra cá, nos anos oitenta eu ainda acho que tinha uma cobrança, agora nem tanto, já é bem mais raro $(\mathrm{H})$.

Para nossas entrevistadas, essas mudanças - que envolvem a queda da taxa de natalidade, o adiamento da gestação e até a opção por não ter filhos - são resultado de fatores econômicos e sociais mais gerais e do investimento da mulher de classe média em uma carreira profissional:

Hoje eu sou uma exceção, talvez amanhã [...] seja o normal, tanto que a gente vive lendo nas entrevistas aí, a natalidade tá caindo violentamente, né, você vê assim é raro, raro ver família com três pessoas, da minha idade, né, é um, dois [...] isso tá mudando agora [...]. Hoje em dia a incidência de mulheres como eu é muito grande também, apesar de que eu acho que aquelas que têm filho é maior, mas as [...] que optaram por não ter filho tá maior e as que têm filho dizem que poderiam ter esperado mais [...]. Eu acho que é uma coisa que vai mudar, a mulher tá cada vez tendo que trabalhar mais, a vida tá difícil, até os espaços estão pequenos (M).

Com a vida que a mulher tem que trabalhar fora, tem muita mulher que apesar de ser casada, às vezes a mulher ganha mais do que o marido, é ela que sustenta a casa, tem muito marido desempregado, eu acredito que não, acho que tem muita gente que opta por primeiro conseguir as coisas pra depois ter filho (S).

Apesar de falarem sobre mudanças, as entrevistadas também afirmam que algumas coisas são muito difíceis de mudar, pois seriam traços característicos da mulher e do homem. Assim, às vezes, práticas e atitudes parecem apenas assumir uma outra roupagem, mostrando que a maneira de pensar certas questões ainda se encontra presa aos padrões de outras épocas:

Casa, trabalho, eu acho que existe uma coisa, eu acho que por mais que mude, existem certas coisas tão entranhadas que talvez até mude e já existem em muitos lugares, mas, por exemplo, quem coordena a casa aqui sou eu, apesar de 
sermos um casal moderno, um casal que as tarefas são bem divididas, a gente divide as contas, divide tudo [...] então existem coisas que talvez a gente esteja numa mudança, mas existem coisas que eu acho que é o dom, é o dom feminino, de guardar, de cuidar, de arrumar, de brincar de casinha, sabe, [...] a gente tem essa necessidade de brincar de casinha, então eu acho que o peso é sempre maior, o peso é maior de cuidar da casa, por exemplo, esses detalhes todos aqui não passariam pela cabeça do $\mathrm{A}$, acabam sendo tantos detalhes que o peso é maior pra gente (M).

Cabe assinalar na fala de $\mathrm{M}$, acima, que os inúmeros detalhes associados às coisas da casa não passam pela cabeça do marido, o que vai ao encontro da antiga idéia de que a mulher é mais detalhista do que o homem.

Tanto $\mathrm{C}$ como $\mathrm{S}$ disseram que não ter filhos é uma opção que se apresenta hoje à mulher. $\mathrm{C}$ diz que é importante respeitar essa opção, mostrando que as pessoas que vivem situações semelhantes tendem a se apoiar. Ela também fala sobre a cobrança que elas devem sofrer, comparando-a com a que ela própria sofria:

Ah, penso, não penso nada demais, assim [...] foi uma opção, né, assim como a gente opta pelo marido, pela profissão, elas optaram por não ter filho [...]. Se elas optaram por não ser mãe elas devem ter os motivos delas, cada uma deve ter seus motivos, não sei, talvez, pode ser, não tem um parceiro, não gosta de criança, quer ter mais liberdade [...] mas acho que deve ser difícil pra elas, né, assim, é difícil bancar essa decisão, porque nem todo mundo, ainda hoje, nem todo mundo aceita né, se me cobravam, mesmo eu querendo filhos, acho que elas devem ser cobradas também, mais que eu, ou não, talvez as pessoas tenham medo de perguntar, não querem saber os motivos, falam só por trás $(\mathrm{C})$.

Apesar de ser uma opção válida hoje em dia, S jamais se viu nessa situação e acredita que talvez essas mulheres que não querem ter filhos não tenham o chamado instinto materno:

Sei lá, eu acho que é uma questão de opção, né, eu acho que quem, talvez sejam as mulheres que não têm instinto maternal, um, não sei, eu não me vejo numa situação dessas, entendeu, não me vejo em hipótese nenhuma, eu poderia até, é, vamos dizer, seria uma opção entre aspas, como eu falei pra você, caso eu não me casasse, não me juntasse com ninguém, não fosse viver maritalmente com 
ninguém, eu não teria filhos [...]. Eu não me vi nunca numa situação dessas, de não querer ter filhos $(S)$.

É interessante assinalar aqui como as mulheres que não têm filhos se referiram à maternidade. Ao comparar suas vidas com a de amigas que têm filhos, disseram não ter inveja do estilo de vida que elas levam, bastante associado a uma sobrecarga de trabalho:

Vejo as minhas amigas com filho, são completamente, a aparência é diferente da minha, o jeito de viver, o estado de espírito, completamente diferente, que a gente faz esporte, ele faz triatlon, eu faço maratona, e eu não quero parar com isso e com filho, pelo menos por um tempo, vai ter que parar e eu não quero perder esse tempo, até vendo, comparando com as minhas amigas que têm filho, uma vida que eu, que eu não tenho nem um pinguinho de inveja (risos) (M).

Eu acho que eu sou (um pouco egoísta sabe), eu gosto assim de na hora que eu quero deitar, eu boto as pernas pra cima, fico tranqüila, enquanto as minhas amigas estão lá, literalmente ralando, sabe, e eu não, acho que eu não gostaria disso, eu não gostaria mesmo $(\mathrm{H})$.

\section{CONCLUSÃO}

Os papéis sexuais tradicionais ditavam que as mulheres deveriam valorizar a maternidade e que era inadequado se elas não se tornassem mães. Assim, era difícil para a mulher abrir mão da maternidade e optar por outras formas de realização.

Atualmente, como se pode observar nesse estudo, parece que a valorização da maternidade ainda se faz presente. Porém o momento nos parece de transição, pois, somado ao antigo papel de mãe e esposa, apresenta-se às mulheres, pelos menos a essas de classe média, a valorização da sua permanência no meio público através do exercício profissional.

Essa coexistência de exigências sociais distintas - as advindas da família e as decorrentes do trabalho profissional - não é pacífica, e muitas mulheres ainda buscam a melhor maneira de lidar com ela. Encontrar uma solução para isso fica a cargo de cada mulher, ou seja, não há uma solução única. Contudo, o que foi possível concluir das falas de nossas entrevistadas é que uma opção excludente - ou o trabalho ou a maternidade - não precisa mais necessariamente ocorrer. Cabe à mulher descobrir os melhores meios, os mais congruentes com suas necessidades, possibilidades e vontades, para fazer com que a conciliação dessas 
duas esferas, ou mesmo a opção por uma delas, se dê da forma menos conflitante, tanto interna como externamente.

Hoje, segundo nossas entrevistadas, outras possibilidades em relação à maternidade parecem estar se abrindo para as mulheres, seja seu adiamento, seja a decisão de não ter filhos. Cabe ressaltar, contudo, que esta escolha está, em grande parte, condicionada tanto pelo contexto imediato quanto pelo contexto mais amplo em que a mulher está inserida.

No que diz respeito à opção por ter ou não filhos, como pudemos observar nos discursos de nossas entrevistadas, apesar de todas elas terem afirmado perceber uma mudança na sociedade com relação à antiga visão de que, para ser completa, uma mulher tem que ser mãe, todas ressaltaram o fato de que a mulher que não tem filhos ainda é vista como uma "coitada", uma "pessoa inferior", alguém que não conseguiu cumprir o seu principal papel.

A esse respeito, ainda, quase todas as entrevistadas se referiram a uma cobrança, especialmente por parte das pessoas da família, de ter filhos, que tem início logo após o casamento. Apesar de sentirem esta cobrança como desagradável, todas afirmaram que aprenderam a lidar, cada uma a seu modo, com essa insistência e essa intromissão alheias.

Podemos dizer que muitas das questôes levantadas no início deste trabalho não têm uma resposta única. $\mathrm{O}$ adiamento da maternidade e a opção de não ter filhos estão intrinsecamente relacionados à história de vida de cada mulher, mas também foi possível observar que outros fatores, em especial o trabalho e a busca de uma estabilidade profissional e financeira, pesam na hora dessa decisão. $O$ sucesso na carreira e a realização profissional e pessoal fazem parte hoje dos objetivos de muitas mulheres e algumas delas abrem mão, inclusive, da maternidade para alcançar esses objetivos. Isto não quer dizer, contudo, que o investimento em um trabalho que lhe dê satisfação seja visto pela mulher atual como mais importante do que ser mãe. Para a maioria das mulheres e para a sociedade, de modo geral, o ideal seria conciliar a maternidade com a realização profissional. Desta forma, parece que a mulher hoje pode e deve encarnar novos papéis sem, contudo, abrir mão do ideal moderno da maternidade, pois só assim ela se tornaria um ser verdadeiramente completo.

Para finalizar, cabe ressaltar aqui que a feminilidade para nossas entrevistadas pode ou não incluir a maternidade, ou seja, realizar-se como mulher não passa obrigatoriamente por ser mãe. Nossas entrevistadas que optaram por não ter filhos, inclusive, afirmaram se sentir plenamente felizes e satisfeitas com a decisão tomada, não se sentindo incompletas nem inferiores por isso. 
Assim, podemos dizer que algumas mulheres atualmente começam a desconstruir antigos determinismos sociais, conseguindo impor suas opções pessoais sobre essas exigências ainda tão fortemente presentes no discurso social. Parece que as opçóes abertas às mulheres continuam a se expandir, mesmo que essas novas escolhas ainda tragam para elas muitas dúvidas e conflitos. Podemos concluir afirmando que diferentes possibilidades começam a se abrir às mulheres de hoje. Um longo caminho, contudo, ainda necessita ser percorrido para que antigas visóes que sempre constrangeram as escolhas femininas sejam de todo erradicadas.

\section{REFERÊNCIAS BIBLIOGRÁFICAS}

Abranches, M. R. J. (1990). Maternidade: sim ou não? Por quê? Rio de Janeiro: FGV/ ISOP.

Badinter, E. (1985). Um amor conquistado: o mito do amor materno. Rio de Janeiro: Nova Fronteira.

Biasoli-Alves, Z. M. M. (2000). Continuidades e rupturas no papel da mulher brasileira no século XX. Psicologia: Teoria e Pesquisa, 16 (3), 233-239.

Bonini-Vieira, A. (1997). Definidas pela negação, construídas na afirmação. A perspectiva de mulheres não mães sobre a maternidade e seu projeto de vida. Dissertação de Mestrado, EICOS, Universidade Federal do Ro de Janeiro.

Rocha-Coutinho, M. L. (1994). Tecendo por trás dos panos: a mulher brasileira nas relaçôes familiares. Rio de Janeiro: Rocco.

- (1998). A análise do discurso em psicologia: algumas questôes, problemas e limites. Em de Souza, L.; de Freitas, M. F. Q.; Rodrigues, M. M. P. (Orgs.). Psicologia: reflexões (im)pertinentes (pp. 317-346). São Paulo: Casa do Psicólogo.

. (2005). Variaçôes sobre um antigo tema: a maternidade para mulheres com uma carreira profissional bem-sucedida. Em Féres-Carneiro, T. (Org.). Família e casal: efeitos da contemporaneidade (pp. 122-137). Rio de Janeiro: Ed. PUC-Rio.

Trindade, Z. A. \& Enumo, S. R. F. (2002). Triste e incompleta: Uma visão feminina da mulher infértil. Psicologia USP, 13 (2), 151-182.

Recebido em 4 de maio de 2007 Aceito para publicação em 16 de agosto de 2007 